\title{
Analysis and Evaluation of the Political Implementation of Land Against Sustainable Food Security in Indonesia (Islamic Economic Approach)
}

\author{
*Hady Sutjipto \\ Department of Economic \\ University of Sultan Ageng Tirtayasa \\ Serang,Banten 42122, Indonesia \\ *hadysutjipto@untirta.ac.id
}

\begin{abstract}
This study aims to analyze and critically evaluate the land policy for food security in Indonesia. This study explains descriptively about the implementation of the management of the policy now practiced in Indonesia. The method used in descriptive and quantitative approaches describes critically evaluating the implementation of land policy in Indonesia in the approach of Islamic Economics. This study uses secondary data derived from books, literature, journal articles and other information related to land policy. The results of the study show that Indonesian land politics are not carried out in accordance with Islamic economics. The fact also shows that the management of agricultural land is still a lot in the form of unproductive and abandoned agricultural land and land and this endangers Indonesia's food security. As a result, farmers continue to suffer losses and dependence on food from abroad. This study suggests that the government in reforming the Agrarian Law implements land politics in the Islamic economy to achieve sustainable food security in Indonesia.
\end{abstract}

\section{Keywords: Land, Sustainable Food Security, Islamic}

\section{INTRODUCTION}

In economic conversation, land and land issues have always been a problem until now, which seems to be endless. Throughout human history, the problem of land tenure has always colored the dynamics of human life. The colonization of a country over another country cannot be separated from this land problem. Large wars between countries, to wars between residents of a village, are also inseparable from this land issue.

Land is the most important production factor which is the most serious study material for economists, because of its special nature which is not possessed by other production factors. These properties include, among other things, land that can fulfill basic human and permanent needs, limited quantity of land and permanent land. Another property is land not labor products. Everything else is labor products except land. In society, land issues have also been the cause of conflict, conflict and bloodshed within the community or between communities. Land also contributes greatly to changes in the structure and system of society.

\author{
Tubagus Ismail \\ Department of Accounting \\ University of Sultan Ageng Tirtayasa \\ Serang,Banten 42122, Indonesia \\ adeismail73@gmail.com
}

Indonesia was once known as an agricultural country. Because, around $80 \%$ of the population depend on their livelihoods from the agricultural sector. Economic development over the past half century has succeeded in changing the structure of the Indonesian economy from an economy based on the agricultural sector to an economy based on the industrial sector. This is evident in the data on the main sectoral contributions. The contribution of the agricultural sector to the economy declined sharply, from $56.3 \%$ in 1962 to only $14.7 \%$ in 2011 , even falling to the level of $13 \%$ in the in 2005 and 2006

But in reality, agricultural commodities have never been the main buffer of the Indonesian economy. The agricultural sector has never placed agricultural products as prima donna of economic commodities that elevate the welfare of farmers in Indonesia. Mastery of agricultural land is increasingly narrowed, even some farmers lose their agricultural land and turn into farm laborers.

Based on the results of the 2003 Agricultural Census, the rate of conversion of paddy fields was around 110,160 ha, of which around $75 \%$ switched to housing, especially in Java (Irawan 2005). This figure is far higher than the ability of the government (Ministry of Agriculture) to print new rice fields which are only around 20,000-30,000 ha (DG PSP 2013). This is exacerbated by the system of inheritance among the community which causes the narrowing of the land area per farmer's household and increasing the number of smallholders with the ownership of rice fields $<0.5$ ha. The number of smallholder farmers was 14.24 million, with the highest distribution in Java Island of 10.18 million households (BPS 2013).

The 2015 BPS report that the volume of imports for food commodities tends to increase, especially for soybeans and wheat. This shows that there will be serious threats related to food security in the future, if there is no action that can reduce the rate of conversion of food land and increase productivity significantly (Mulyani.2016).

This condition is compounded by the government's policy of being increasingly impartial to farmers and even more 
burdensome to farmers. Reducing farmer subsidies in the form of fertilizers and agricultural production facilities in the form of pesticides and agricultural equipment causes the price to continue to soar. The policy is to open wide the tap for imports of cheap agricultural commodities from abroad, thus shutting down local agricultural products. It will all add to the suffering of the peasants.

On the other hand, the phenomenon of riots after riots due to land disputes continues to color the lives of people in this country. Both disputes between individuals in the community, disputes between countries and companies, as well as disputes between countries and communities. Not a few victims fell due to the dispute.

Reform of the Basic Agrarian Law in Indonesia raises five problems, namely (1) the social function of the land, (2) the maximum limit of land ownership, (3) ownership of stalled land, (4) Monopoly of land ownership, and (5) determination of compensation land loss. These five things often trigger the emergence of land conflicts that are not easily resolved.

The phenomenon that emerges in land tenure problems in the economic review is that there are individuals or private parties who can control land on a very large scale, while on the other hand there are many individuals who only control small amounts of land, and even have no land at all. So, he only becomes a farmer of land, or known as a farm laborer, whose life is getting poorer, suffering and oppressed.

The most prominent fact in the land problem is the emergence of injustice or imbalance in land tenure. The economic system of capitalism and socialism in this case is more or less triggered by social jealousy of people who own land because of their privileges and make it a means of exploitation of society.

Land ownership is considered to be the most special type of ownership in capitalist countries. Land can be owned by individuals as broadly as possible, even renting it out to the public with rental prices and selling prices carried out arbitrarily. As a result, prices of basic commodities rose and inflation occurred. For the country, land becomes fertile ground for tax revenue. Henry George's movement on single tax (1886), which had millions of followers in the United States, based on such facts he argued that in principle land leasing would provide added value and could therefore be subject to high taxes without the need to change production incentives.

But individual ownership of land is not recognized in socialist society. Farmers and workers are prohibited from taking added value from their work, and their status is merely as farm laborers. This system factually caused economic inequality and made socialist countries failed to achieve food self-sufficiency in the mid-twentieth century. They still depend on other countries to meet their food needs.

Therefore, so that all land in a country can continue to increase its productivity in achieving sustainable food security, then the right strategy or policy is needed to make it happen.
At the same time, how can land tenure be distributed fairly and equitably to all people can be created?

The problem is: what and strategies or policies that can play a role in realizing these expectations? Until now the issue of land policy still remains unanswered by capitalist and socialist economics. The question is, is the existing Economic System capable of resolving all of these land problems thoroughly and fairly for all humanity on this earth?. Research question:

On the basis of the above background, the formulation of the problem in this study is as follows:

1. Why is land politics needed to achieve sustainable food security in Indonesia?

2. How is the construction of land politics to realize Indonesia's sustainable food security with an Islamic economic approach?

\section{DISCUSSION}

During this time the agricultural sector is the sector that received the least attention from the government. The discussion about agriculture is generally done without being associated with other sectors. As a result, economic development is seen as a separate part of development in other fields such as industry, trade and services and other economic sectors. Though this narrow view is what causes agricultural development in developing countries to be very far behind compared to agricultural development and economic development of developed countries.

Agriculture is an integral part of various other fields such as industry, trade, services, land and so forth. Everything is an integral part that is closely related. Therefore, when Islam talks about the politics of agriculture, industrial politics, land politics, labor politics, trade politics - both domestic trade and foreign trade - all are discussed in one unit that is closely related. All of these fields in the perspective of Islam are directed towards efforts to achieve the achievement of political economic objectives according to Islamic economics. Islamic economic policy is the application of various policies that aim to ensure the fulfillment of all the basic needs of each individual in the community as a whole, accompanied by a guarantee that allows each individual to fulfill complementary (secondary and tertiary) needs according to their abilities.

In order to achieve the realization of such economic political goals, the politics of Islamic agriculture is carried out. The politics of Islamic agriculture can be seen from various policies that should be pursued by the state in the field of agriculture, both the production sector (primary), industrial sector (secondary) and trade and services (tertiary). Therefore, when discussing the politics of Islamic agriculture, then that means we will discuss the politics of agriculture in the sector of production, processing (industry), and trade and services. This is because in the eyes of the Islamic economy, the agricultural sector is closely related to the industrial sector, 
trade, services and is also inseparable from the land sector. Or in other words agricultural politics according to Islam is closely related to industrial politics, trade politics, labor politics, land politics and so on.

A. Agricultural Land Policy in Indonesia

The regulation of agricultural land in Indonesia comes from the establishment of the Agrarian Law which regulates the policy of controlling agricultural land. The Agrarian Law applied in Indonesia is a continuation and improvement of the Agrarian Law of the Dutch heritage. As we understand that the Netherlands is one of the European countries oriented to the capitalist economic system in its economic arrangement, including in the agrarian arrangement. The regulations governing the issue of land in Indonesia are minimal. The only rule that exists is only the Basic Agrarian Law Number 5 of 1960. The Government and Parliament are currently preparing to discuss the Land Law Draft as a priority in 2018.

Every economic system will certainly have basic views in giving birth to its regulations, including to regulate the procurement of agricultural land. In the view of the capitalist economic system, several important principles that will underlie the control of agricultural land are:

1. The essential justice in the procurement of agricultural land is the granting of equal rights in ownership of agricultural land to all citizens.

2. Every citizen is free to own agricultural land no matter how wide.

3. Every citizen is free to use his agricultural land, for any benefit and production.

4. Every citizen is free to develop and increase ownership of his agricultural land.

If we examine the views of the capitalist economic system in regulating the control of agricultural land, at first glance it appears that the arrangement is a fair arrangement for all citizens. Every citizen is given the same opportunity to own and expand the ownership of his agricultural land. There are no restrictions and discrimination for every citizen.

It turned out that in the course of history, it was proved that the arrangement had brought havoc to most people, especially among the farmers. Why is that? If the principle of freedom in the control of agricultural land is implemented, it will have the following impacts:

1. The emergence of unlimited free competition in the ownership of agricultural land.

2. The occurrence of an imbalance in the ownership of agricultural land.

3. The owner of a large agricultural land, will be even bigger and continue to expand to increase the ownership of his land.

4. Farmers who own small land will increasingly narrow their ownership of agricultural land.

5. Many farmers lose ownership of their agricultural land and become farm laborers.

6. The culmination was the occurrence of feudalism in agriculture.

\section{B. Land Politics According to Islamic Economics}

Until now the issue of ownership and ownership of land is still the main agenda of the economy. In several feudal countries where land was dominated by landlords, ownership inequality was solved by land reform. Japan, South Korea and Taiwan are the most intense countries in modern history running land reform after the second world war. Land reforms are carried out with the aim of eliminating, psychologically and materially, landlords who are the driving force behind these countries to wage war. This reform has had a profound impact on equalizing the distribution of income in the countryside and contributing to maintaining income differences between cities and villages so that they become narrower than other countries. As a result of these reforms, the strength of the feudal people became destroyed, eliminating the rent of agricultural land and limiting the ownership of cultivated land.

Islamic economics considers land ownership to be properly regulated because it influences production stimuli. Islam expressly rejects the system of equal distribution of land tenure among all societies as is the agenda for land reform. However, Islam also does not permit excessive land ownership beyond the ability to manage it. Therefore, the laws surrounding the land in the view of the Islamic Economy have distinctive characteristics with the existence of principle differences with other economies.

Islamic Economics recognizes that land is included in the category of individual ownership if there are no elements that prevent it, such as the presence of mining material or controlled by the state. When this ownership is considered valid in sharia, the landowner has the right to manage it or transfer inheritance, sale and purchase and purchase. As with other individual ownership, ownership of this land is certain without other parties being able to revoke their rights. The state protects the property of citizens and protects it from the threat of interference from other parties.

The solution to Islamic economics is the unification of the ownership of agricultural land with its production. Conclusion This solution was extracted from 3 laws at once. The three laws are: (An-Nabhani, 2009; Al Maliki, 2009, Az-Zain, 1998)

\section{a. Turn on the Dead Land}

This law allows each individual to have a dead, empty, and abandoned land, which does not appear to have a fence, cultivated plants, buildings and so on, by turning it on or fencing it as wide as anything he wants. This ownership right is determined based on several hadiths of the Messenger of Allah.

"Anyone prospering the land that is not owned by anyone, then he has the right to the land." (Ahmad)

"Anyone who has fence a plot of land with a fence, then the land is his property" (Abu Daud)

"Whoever has turned on a piece of dead land, the land is his property" (Abu Daud, Tirmizi, and Ahmad) 
The arguments above show that the Islamic economy provides convenience and simplicity to every individual of the people to own any land by turning on or fencing it. The condition is that the land is a land that is still abandoned, no one has.

b. The law prohibits abandoning agricultural land for more than three years

Although Islamic economics provides convenience and freedom to individuals to own any land, by turning it on or fencing it, there is a limit to the ease. The limit is the prohibition to abandon the land for more than three consecutive years. The prohibition was determined based on several hadiths of the Prophet. :

"Anyone who has turned on a dead land, then he is the owner. And there is no right for those who fence after abandoning their land for three years "(HR. Baihaqi)

Yunus told of Muhammad bin Ishaq from Abdullah bin Abu Bakr saying: "Bilal bin Al-Harith Al-Muzni came to the Messenger of Allah, then he asked for a plot of land to him. He then gave him a large piece of land. "When the government was led by the caliph Umar, he (Umar) said to him:" O Bilal, you have asked the Prophet for a large piece of land. Then he gave it to you. And the Messenger of Allah. never refused to be asked at all, while you are not able to (cultivate) the land in your hands. "Bilal replied:" Right. "Umar said:" Look, which of these lands you can work on, then have it. And what you cannot work on, leave it to us, and we will share it with the Muslims. "Bilal said:" By Allah, I will not do at all and give what was given by the Messenger of Allah. "Umar said:" By Allah, you should really work on it. "Then Umar took the land he could not cultivate from Bilal, then he shared with the Muslims.

The state as the party that controls the economic activities of its citizens will force agricultural landowners to manage their land optimally. The step taken by the state is to take ownership rights if the person ignores it for three years. The land will then be given to those who need it and are able to manage it. Thus, ownership of land is essentially not limited by a certain time. Land is still entitled to be owned with all the rights that accompany it as long as the person in question manages it according to its use. Islam only limits the period of neglect for a period of three years.

Umar bin Khaththab r.a. said: "The person who is guarding the land is not entitled (to the land he has fostered) after (leaving it) for three years."

Yahya bin Adam recited through the Amad bin Shu'aib sanad said: "The Messenger of Allah. had given a plot of land to some people from Mazainah or Juhainah, then they ignored it, then there was a people to turn it on. Umar said: "If the land were given from me, or from Abu Bakr, of course I would return it, but (the land) from the Messenger of Allah." $\mathrm{He}$ (Amru bin Shu'aib) said: "Umar said: 'Whoever ignoring the land for three years, which he did not manage, then someone else managed it, then the land was his property. "
This Hadith explicitly explains, that if the landowner is unable to work on the land and leave it for three years, then the land will be taken by the state from its owner and given to others, as Umar bin Khaththab did to Bilal AI-Muzni against the mine which his tribe had - which was next to Fara 'in the Hijaz region.

The takeover of abandoned land for a period of three years applies to all types of agricultural land, whether obtained from purchases, inheritance, gifts, state gifts, or living dead land. This is because the legal reason for revoking the land is neglect for three years regardless of the type of land. So, every land owner who leaves his land for three years, then the land will be revoked and given to other people, from where the ownership of the land originates. This cannot be considered to have taken other people's property in an illegal way. Because, sharia has made the ownership of agricultural land managed. All of this is so that the land is always planted and managed optimally.

Therefore, a land owner may plant his land with his tools, seeds, animals and workers. He may also employ workers to plant it. If he is unable to work for him, then he will be assisted by the state. However, if the land is not planted by the owner, then the land will be given to another person as a free gift, without any compensation, then he works on it. If the owner does not work on it and still controls it, then it will be left for three years. If the land is left - without being managed - for three years, the state will take the land from its owner and give it to others. For anyone who needs (maintenance costs) will be given something (capital) from Baitul Mal, so that the person concerned can manage it optimally.

With the two legal provisions above, Islamic economics requires that land ownership for individuals must be integrated with their willingness to produce it. It is not permissible to only own land, but do not want to produce it.

Of the two laws, there is still a gap, one can have a large area, but he does not want or is unable to produce it. So he will rent it to someone else to work on it, so that the land will continue to produce, so he hopes that he will not lose his land ownership. Apparently there is a third legal provision.

\section{c. The law prohibits leasing land for agriculture}

An absolute landowner may not rent out his land for agriculture. He is not allowed to rent land for agriculture with rent in the form of food or something else, which is produced by the farm, or whatever is produced from there, because everything is ijarah. Renting land for agriculture is absolutely prohibited.

"The Messenger of Allah. prohibit taking rent or parts of land "(HR. Muslim)

Narrated, "The Messenger of Allah. prohibit renting out land. We ask: O Messenger of Allah, then we will rent it out with seeds. He replied: 'Don't. 'Ask (friends): " We will rent it out with straw. He replied: "No." Asking (friends): 'We will 
rent it out with something above the rabbi. He replied: "No. You plant or give the land to your brother. "(HR. Imam Nasa'i)

In the saheeh hadith it is stated: "That he (the Prophet) forbade the taking of rent and the upper part of a land, and rented out with a third or a quarter." Imam Abu Daud related from Rafi 'bin Khudaij, that the Messenger of Allah. said: "Anyone who has land, should plant his land, or should (be given) planted by his brother. And do not rent it out with a third, a quarter, or with food that is equivalent. "

The above hadiths clearly show the prohibition of the Messenger of Allah. against land leasing. The prohibition shows that there is an order to leave it and contains an indication that explains the existence of a strict prohibition. Islamic economic alternatives about this, is to employ other people to manage the land or if it is not capable at all, the land should be given to others as mentioned in the hadith:

The prohibition on leasing agricultural land economically can be understood as an effort to enable agricultural land to function optimally. This means that someone who is able to cultivate land must own land while anyone who is unable and unwilling to cultivate the land is not allowed to control agricultural land.

However, the prohibition on leasing the land is only valid for agricultural purposes (to be planted with certain plants, so that the results can be harvested). While freedom is not for other purposes, such as leasing for livestock, fisheries, buildings, and industry, it is permissible. These exceptions are based on the above hadith only intended for agricultural land.

By applying the solution of Islamic economics, namely the unification of the ownership of agricultural land and production, the impact is expected to have two things, namely: (i) Increased agricultural production. Islam provides freedom for individuals to own any land, as long as they are able to produce it. It is expected that there will be no vacant land idle, not exploited at all. Originally agricultural land is expected to be always productive. Islam also frees to develop any agricultural commodities. This guarantees increased diversification and productivity. (ii) Economic equality in agriculture. With the prohibition of abandoning and renting agricultural land, it is hoped that greed in land ownership can be more controlled. Thus, the opportunity for farm laborers to own their own agricultural land is increasingly open. The skills of farmers get high appreciation. Because, for large landowners, if they are not able to work on it, they can pay farmers high wages. If you do not want to give high wages, farmers just wait 3 years to have land that is not cultivated, by working on it.

That is the picture of land politics in Islamic economics that regulates the issue of agricultural land control. A fair solution for humans, as well as a solution that can bring prosperity together in agricultural productivity. In the end this policy will realize sustainable food security.

\section{CONCLUSION AND SUGGESTION}

Based on the analysis that has been carried out obtained some conclusions in this study: The Indonesian state still adopts the feudal land law and is still minimal in regulating and solving land issues that are developing at this time. This can be seen from the ownership of agricultural land is still controlled by landlords and the management of agricultural land is still a lot in the form of rent and unproductive and abandoned agricultural land. This is not in accordance with the concept of Islamic economics. The impact of this condition causes freedom in the conversion of agricultural land and endangers food security. The absence of land politics in synergy to realize sustainable food security in Indonesia. Land politics in Islamic economics provides construction in the form of unifying agricultural land ownership and production so that increased production and economic expansion in agriculture can be achieved to achieve sustainable food security in Indonesia.

Based on the conclusions that have been described, the suggestions that can be given to the responsible party of Indonesia are: The government immediately conducts an evaluation and restructuring of the policy on the use of agricultural land.. The government conducted an assessment to implement the Islamic Economic system in its operations in reforming the land law. The state must abolish the agricultural land rental system, because this is contrary to the Islamic economy, and returns to the management system of agricultural land by the landowners. The government must implement agricultural land policies by integrating agricultural land ownership and production, so that agricultural production can be increased and economic equity in agriculture can be realized.

\section{REFERENCES}

[1] Al-Baghdady. A. (1987). Islamic Law Series: Land Leasing; Dark Wealth; Length, Area, Size and Scales. Bandung: Publisher. Al-Ma'arif.

[2] Al-Maliki, Abdurrahman (2009). Politics of Islamic Economics. Bangil East Java. Al Azhar Press.

[3] Amir, H. (2014). Agriculture in the Structural Transformation of the Indonesian Economy. In F.Saragih, H. Amir, \& Insyafiah (Eds.), Agricultural Sector Financing Program. Jakarta: Nagamedia Library.

[4] An-Nabhani, Taqiyuddin. (2009). Establishing an Islamic Economic Alternative Alternative System. Jakarta: Al-Azhar Press.

[5] CSA (2013). Agricultural Statistics 2013. Central Statistics Agency. Jakarta, Indonesia.

[6] CSA. Statistics Indonesia 2016. Central Statistics Agency. Jakarta, Indonesia.

[7] Chapra, M. U. (1999). Islam and Economic Challenges: Islamization of the Contemporary Economy. Surabaya. Announcer of Risalah Gusti.

[8] Condro T, Dwi. (2011). Hamfara Islamic Economics, Islamic Economic Philosophy, Volume 1, Irtikaz,

[9] Deliarnov. (1997). Development of Economic Thought, Jakarta: PT. Rajawali Persada

[10] Irawan, B. 2005. Rice Field Conversion: Potential Impacts, Utilization Patterns and Determinant Factors. Agro Economic Research Forum, volume 23, No. 1, July 2005. Hal. 1-18.

[11] Ministry of Agriculture (2015). Food Security Agency Strategic Plan for 2015-2019. Indonesia. 
[12] Mubyarto. (1995). Introduction to Agricultural Economics. Jakarta. LP3ES Publisher.

[13] Mulyani, A, Kuncoro D, Nursyamsi D, Fahmuddin A. (2016). Wetland Conversion Analysis: Use of High Resolution Spatial Data Shows Worry Conversion Rate. Journal of land and climate Vol. 40 No.2 p.121-133.

[14] Murad, Rusmadi. (2013). Land Administration Implementation of Land Law in Practice. Bandung: CV Mandar Forward

[15] DG of PSP. (2013). Potential for land use transfer due to LP2B not being stipulated in the regency / city RTRW. Materials displayed at the Directorate General of PSP. Directorate General of Agricultural Infrastructure and Facilities. Jakarta

[16] Yusanto, Ismail, Yunus Arif. (2009). Introduction to Islamic Economics. Bogor. Al-Azhar Press.

[17] Zain, Samit Athif (1988). Islamic Shari'a in the Economic, Political and Social discussion of various Comparative Studies. Bandung. Husaini 